\title{
Plant Exit and U.S. Imports from Low-Wage Countries
}

\author{
David L. Rigby ${ }^{1}$, Thomas Kemeny ${ }^{2}$, Abigail Cooke ${ }^{3}$ \\ Accepted Version: Paper published in International Economics, \\ DOI: http://dx.doi.org/10.1016/j.inteco.2016.09.001
}

\begin{abstract}
Over the past twenty years, imports to the U.S. from low-wage countries have increased dramatically. In this paper we examine how low-wage country import competition in the U.S. influences the probability of manufacturing establishment closure. Confidential data from the U.S. Bureau of the Census are used to track all manufacturing establishments between 1992 and 2007. These data are linked to measures of import competition built from individual trade transactions. Controlling for a variety of plant and firm covariates, we show that low-wage import competition has played a significant role in manufacturing plant exit. Analysis employs fixed effects panel models running across three periods: the first plant-level panels examining trade and exit for the U.S. economy. Our results appear robust to concerns regarding endogeneity.
\end{abstract}

Keywords: international trade, low-wage country import competition, plant exit

JEL Codes: F14, F15, F16, L6

\section{Disclaimer}

This research uses confidential data from the U.S. Bureau of the Census. Any opinions and conclusions expressed herein are those of the authors and do not represent the views of the U.S. Census Bureau. All results have been reviewed to ensure that no confidential information has been disclosed.

\footnotetext{
${ }^{1}$ Departments of Geography \& Statistics, University of California Los Angeles, Los Angeles, CA 90095, USA. Email: rigby@geog.ucla.edu

${ }^{2}$ School of Geography \& Environment, University of Southampton, Southampton SO17 1BJ, UK. Email:

T.E.Kemeny@soton.ac.uk

${ }^{3}$ Department of Geography, University at Buffalo, Buffalo, NY 14222, USA. Email: amcooke@buffalo.edu
} 


\section{Plant Exit and U.S. Imports from Low-Wage Countries}

\section{Introduction}

Between 1992 and 2007, U.S. imports increased by a factor of 2.5, climbing above the \$2 trillion mark. Over the same period, imports to the United States from low-wage countries grew by a factor of almost 10. Increased global economic integration holds the potential to dramatically change labor market dynamics and industry structure in both developed and developing countries (Baldwin 2006; Blinder 2006; Autor et al. 2012). Recent evidence from advanced industrialized economies such as the United States confirms this intuition: workers in these countries have been affected by rising imports in various ways (Kletzer 2002; Ebenstein et al. 2009). Potential impacts are likely to be largest in relation to trade among economies whose factor endowments are fundamentally different, such as between economies that have an abundance of low-skill labor and those that are abundant in highly-skilled workers (Feenstra 2008). Following this logic, researchers have found that import competition from low-wage economies like China is associated with a variety of negative labor market effects in developed economies, from job loss, to increases in government transfers, and reduced long-run earnings (Pierce and Schott, 2012; Autor et al. 2013; Kemeny et al. 2015). In keeping with the recent growth of low-wage imports, estimates of these impacts over the 1990s and 2000s are far larger than those documented by researchers looking for trade effects in the 1980s (Lawrence and Slaughter 1993; Berman et al. 1994; Sachs and Schatz 1994).

One way that import competition can affect workers is by inducing the establishments in which they work to shut down, or 'exit' (Bernard et al. 2006; Eriksson et al. 2009; Inui et al. 2009; Colantone \& Sleuwaegen 2010; Baldwin and Yan 2011; Wagner 2011; Colantone et al. 2014). Although this relationship has received considerable attention, to date the models that link import competition and plant exit rarely control for unobserved heterogeneity at the plant/firm level. This is an important omission. It is reasonable to assume that a variable such as managerial expertise is effectively fixed over short time-periods within plants/firms and that this variable will be correlated with most measures of plant/firm performance. Resulting estimates using pooled, independent cross-sections will thus be biased and inconsistent (Wooldridge 2002). We remedy this concern using a three period variant of the traditional fixed effects panel model. The paper also adds value by updating the earlier findings of Bernard et al. (2006) and Bernard and Jensen (2007) for the United States, and by extending the analysis to consider a number of interactions between import competition and plant/firm characteristics for the U.S. economy.

Consistent with past results, notably the findings of Bernard et al. (2006), we find that rising import competition from low-wage economies increases the probability of manufacturing plantexit. Industry-specific import competition from high wage countries also increases the likelihood of exit, though the size of the effect is much smaller than competition from low-wage countries. Several factors act to insulate plants and protect against exit. Larger plants, older plants and those that export have lower probabilities of exit. In line with Bloom et al. (2011), we find evidence that higher productivity plants, those with higher levels of capital investment per worker and those with higher ratios of capital investment devoted to computing equipment, a proxy for technology, are less likely to exit markets when the intensity of low-wage import 
competition increases. Like Bernard and Jensen (2007) we report that imports from low-wage countries are more likely to push plants that are part of multi-establishment firms to exit relative to single-plant firms. However, we also show that the plants of firms that have foreign affiliates in low-wage countries are less likely to exit than plants overall. Additional evidence of the protective nature of plant-level productivity within multi-unit firms is found, and new information about how low-wage country import competition interacts with other plant-level and firm-level characteristics is presented. Results are obtained from linear probability models in fixed effects panel form and from panel models incorporating instrumental variables.

The paper is organized in five sections below. In Section 2, the recent theoretical and empirical literature that underpins our analysis is briefly discussed. Section 3 outlines the linked data sets that we have employed. Section 4 presents the analytical approach. In Section 5 the main results of the analysis are detailed and a short conclusion is offered in Section 6.

\section{Literature Overview}

There is growing evidence of firm heterogeneity with respect to trade (Aw and Hwang 1995; Clerides et al. 1998; Bernard and Jensen 1999). Persistent intra-industry differences in plant and firm performance, differences correlated with export status, are inconsistent with Krugman's new trade theory and its assumption that all firms export. A so-called "new new" trade theory emerged with the work of Melitz (2003), Bernard et al. (2003) and Helpman et al. (2004). At the core of these new theoretical models of trade is firm heterogeneity and an assumption that the sunk-costs of entry into export markets can be borne only by more productive businesses. Though these models generally assume the market structure that they seek to explain, the relationships between firm characteristics, trade and market dynamics that they outline have become standard tools for exploring competition in an increasingly integrated global economy.

For Melitz (2003), entrants to an industry are identical and heterogeneity is generated through a random productivity draw that follows payment of fixed entry costs encouraged, in turn, by the possibility of profit. This productivity draw is consistent with the idea that firms do not know their productivity until they enter the market and begin production. An additional fixed cost to enter export markets partitions firms into exporters or non-exporters depending on their productivity levels. In this fashion, the positive correlation between exporter status and firm productivity is captured. Melitz (2003) shows that trade-based competition lowers the revenues of non-exporting firms as foreign exporters are on average larger and more efficient. Consequently, the least efficient non-exporters may be forced to exit the industry. At the same time, more efficient firms that export gain market-share and capture additional profit.

Bernard et al. (2003) offer a model of production and trade under imperfect competition. By allowing differential plant mark-ups, variations in efficiency give rise to heterogeneity in measures of plant-level productivity, consistent with available data. As in Melitz (2003) initial levels of plant efficiency are established as a random drawn from an efficiency distribution. Assuming that the costs of overcoming trade barriers prevent less efficient plants from exporting, Bernard et al. (2003) establish the positive relationship between plant-level productivity and export behavior. Variable costs and market-size structure the intensity of competition and firm dynamics in this model. Helpman et al. (2004) extend similar arguments about firm 
heterogeneity, productivity and the costs of serving foreign markets to examine the decision to export or to engage in foreign direct investment. Assuming the fixed costs of FDI exceed those of exporting, they show that only the most productive subset of firms with an international presence invest in a foreign production facility and that decision is made in terms of market access. Head and Ries (2003) provide additional arguments motivating FDI choice. Antras and Helpman (2004) and Antras and Rossi-Hansberg (2008) develop these claims further, exploring how incomplete contracting can help explain the organizational choices of firms that trade. Further extensions of these arguments explore the distribution of exports across countries (Eaton et al. 2008), provide a framework for understanding the scope of heterogeneous firms with respect to the variety of products exported and the choice of export markets (Bernard et al. 2011), and investigate the decision to integrate or outsource production in domestic or international settings.

These theoretical claims undergird a rapidly expanding empirical literature that highlights firm heterogeneity in relation to international trade. Much of the work is concerned with exports and entry, specifically seeking to understand whether entry into exporting confers productivity advantages upon the exporters; the counterfactual is that only the most productive firms select into exporting activity. Wagner (2007) and Greenaway and Kneller (2007) provide detailed surveys of this literature. Links between imports and entry and exit are less well developed. However, recent papers point to a positive link between import status and firm performance that echo findings on the export side (Amiti and Konings 2007; Castellani et al. 2010). Causality is likewise still an issue, though there is a large body of work that suggests firms importing intermediate inputs, whether at arms-length or as a result of offshoring, enjoy significant productivity advantages (Vogel and Wagner 2010; Bas and Strauss-Kahn 2014).

An even smaller body of work links imports to plant exit, taking well-known plant-exit arguments (see Dunne et al. 1989; Baldwin and Gorecki 1998) and grafting onto these models measures of trade-related characteristics at either the plant, firm or industry levels. Across a number of emerging economies, the focus has been directed at trade liberalization, increased foreign competition and the reallocation of resources across producers within industrial sectors. Thus, Pavcnik (2002) explores the impact of trade liberalization through the 1970s and early 1980s in Chile. Controlling for plant characteristics, she reveals that the elimination of non-tariff barriers and significant reductions in tariffs were associated with marked productivity gains within industries: those gains won, at least in part, by the elimination of less-efficient plants. Alvarez and Vergara (2010) update results from Chile, examining trade policy reforms up to 2000. They show that liberalization increases plant exit in smaller and less-efficient plants, especially plants in export-oriented sectors. Amiti and Konings (2007) report the exit of less efficient firms in their analysis of tariff cuts for both intermediate inputs and final goods in Indonesia. Eslava et al. (2013) show that trade liberalization in Colombia tightens markets and the resultant intensification of competition is more likely to increase exit for less productive plants. Results from analysis of tariff reductions and plant exit from more developed economies are broadly similar. Lileeva (2008) shows that the Canada-U.S. Free Trade Agreement induced a significant shift in exit rates among non-exporting Canadian manufacturing plants. Baldwin and Yan (2011) report similar findings though results from New Zealand are somewhat more mixed (Gibson and Harris 1996). 
Within advanced industrial economies, more generally, examination of the impacts of trade on plant exit have tended to focus on rising import competition rather than shifts in tariffs. The sharp rise in import competition tends to be viewed as a reflection of the growth of industrializing economies and the associated rise in offshoring, manifest through both armslength and multinational subsidiary arrangements. In a seminal paper, Bernard et al. (2006) show that rates of exit among U.S. manufacturing plants are higher in industries characterized by greater import competition from low-wage countries. Similar results are presented for Belgian firms by Coucke and Sleuwaegen (2008), and Greenaway et al. (2008) show that exit rates for Swedish plants are also higher in industries facing more severe import competition from nonOECD nations. However, in their survey of Belgian plants, Mion and Zhu (2013) report no relationship between firm survival and import competition. Likewise, Inui et al. (2009) find no significant effect of import competition on plant exit in Japan. In an interesting South-South comparison, Alvarez and Claro (2009) show that that the probability of exit is higher for Chilean plants confronting a steep increase in import competition originating from China.

While import competition, especially from low-wage countries is generally seen as a driver of plant exit, a new series of studies complicate the links between globalization and firm survival. Thus, plants that export are typically found to be less susceptible to exit than those that do not export (Esteve-Perez et al. 2008; Greenaway et al. 2008; Gorg and Spaliara 2010). In a different twist, Lopez (2006) shows that plants that import intermediate inputs have a higher probability of survival. This, in turn, might be related to the product-upgrading induced by low-wage import competition discussed by Bernard et al. (2006). Considerable evidence suggests that firms with different productivity premia self-select into different types of engagements with the global economy, ranging from arms-length importing and exporting of intermediates and final goods, through to offshoring to wholly-owned affiliates. Many of these choices are linked to plant and firm survival. Looking at some of these broader firm characteristics, Bernard and Jensen (2007) show that the plants of multi-unit and multi-national firms are more likely to exit than their single-establishment firm counterparts. Bandick (2010) illustrates the complex relationships between firm survival, multi-national status and foreign/domestic ownership in Sweden. Bloom et al. (2011) explore the influence of Chinese import competition on European firms. They show that low-wage import competition induces technological upgrading and that improved technology insulates some firms from job-loss and higher probabilities of failure.

To date, almost all the literature on plant-exit and trade follows the general structure of the model laid out by Bernard et al. (2006). This is essentially a cross-sectional design, taking plantand firm-characteristics at time $t$ and exploring their relation with plant exit at some future time $t+n$. One important weakness of such an approach is the inability to account for unobserved heterogeneity at the plant level. We address this issue by estimating panel models of exit that explicitly deal with stationary forms of unobserved heterogeneity within manufacturing establishments. To the best of our knowledge, this is the first paper to examine the relationship between import competition and plant exit in the United States controlling explicitly for plant/firm-level fixed effects. We also extend the standard plant-level accounts to examine a number of firm characteristics and their relationship to exit. We turn to the data in the next section. 


\section{Data}

\subsection{Sources}

Investigating the impacts of trade on the probability of manufacturing plant exit in the U.S. economy requires import and export data along with measures of the characteristics of manufacturing establishments (plant and firm level data). These data are readily available from the U.S. Bureau of the Census through the Federal Statistical Research Data Center network. The trade data originate in the Foreign Trade Division of the U.S. Census Bureau. The aggregated, public data on U.S. imports and exports are built up from individual import and export declarations submitted to the U.S. Customs and Border Protection Service. These individual records are available annually for the period 1992-2007 and cover all import declarations exceeding \$2000 in value (\$250 for certain quota items). Import declarations for shipments less than $\$ 2000$ in value are imputed. The individual import declarations contain information on the principal party of interest, the name and address of the business that is the major beneficiary of the traded commodities, and which is typically the importer of the products detailed in the declaration. The trade declarations also provide Employer Identification Numbers (EINs) that help identify the importer of record. Shipper's Export Declarations (SED) cover all export bundles exceeding \$2500 in value (\$250 for certain quota items). The SED data record the country to which the exports are being shipped, a 10-digit product code consistent with the Harmonised Commodity Description and Coding System, a NAICS code, the physical quantity of a product shipped along with its value, and identifying information on the firm that exports (the EIN). From 1990, the SED is not required in the case of exports to Canada. Statistics Canada generates data on imports from the U.S. that are used by the Census to construct exports to Canada.

Imports and exports are classified using either Schedule B commodity codes or commodity codes of the Harmonized Tariff Schedule. The first six-digits of both these schemes are consistent and can be liked to SIC/NAICs codes using concordances of the Census Bureau (,www.census.gov/foreign-trade/ reference/codes) or of the United States International Trade Commission. These concordances allow translation of import/export commodity groups into the industry categories of the Standard Industrial Classification (SIC) or the North American Industry Classification System (NAICS). We use the transaction level trade data and make use of NAICS in the analysis below.

The Longitudinal Business Database (LBD) of the U.S. Bureau of the Census contains the universe of all U.S. business establishments with paid employment. The LBD contains names and address information, employer identification numbers and wage and employment data for all establishments. The LBD includes data for manufacturing and non-manufacturing businesses such as the age of plants, as well as information on the individual establishments that comprise multi-unit firms. Unfortunately, the LBD does not contain a great deal of information on the characteristics of individual business establishments beyond basic identifiers and overall employment data. A much broader list of establishment characteristics for manufacturing plants is available from the Census of Manufactures (CM) for all years ending either in a 2 or 7. CM data are utilized for the years 1992, 1997, 2002 and 2007 for this study of manufacturing plant exit. The CM contains valuable information on plant-level inputs and outputs, including value 
added, production and non-production employment, capital stocks, overall capital investment, the share of that investment devoted to computers and machinery, and estimates of total factor productivity. The manufacturing plant-level data can be linked to the LBD, to firms and thus to the trade data discussed above through EINs and other plant-firm identifiers (see Bernard et al. 1995). Analysis of the impacts of trade from low-wage countries on plant exit is limited to the manufacturing sector of the U.S. economy. In large part this reflects the paucity of trade data for other parts of the economy.

\subsection{Measures of Trade Competition}

To gauge the impact of trade on U.S. labor markets and on plant exit requires a measure of tradebased competition. A relatively standard measure of import competition indicates the extent to which imports comprise the overall value of a product available for U.S. domestic consumption. That measure is adopted here, limiting the import term in the numerator to the merchandise that originates in low-wage countries

$$
L O W_{-} W A G E_{-} I M P C O M P_{i t}=\frac{L O W_{-} \text {WAGE_IMPORTS }}{\text { SHIPMENTS } \text { It }_{i t}-\text { EXPORTS }_{i t}+\text { IMPORTS }_{i t}}
$$

where $i$ indexes product type or industry and $t$ indexes the year.

The subset of low-wage countries is identified by the World Bank on the basis of GDP per capita data for the year 1992, the first year of analysis. The set of low-wage countries is fixed over the years examined. The World Bank classifies economies into one of four broad groups: low income, lower middle income, upper middle income and high income. Low-wage countries in 1992 were defined as those economies with average annual gross national income below (U.S.) $\$ 545$. Table 1 lists the 51 countries that comprise this grouping. Note that this group includes relatively large economies that export high volumes of output to the United States such as China and India. Across Latin America and the Caribbean, the only countries that are part of the lowwage group are Guyana, Haiti and Honduras. World Bank lists of low-wage countries are quite broadly employed in the trade and development literature (see Arvis et al. 2016; Autor et al. 2012; Djankov 2010; Easterly 2005; Freund, 2009), though note that membership on these lists varies by year. The list of low-wage countries employed in this paper is slightly different from that employed by Bernard et al. (2006), though both lists include China. To the extent that the rise of U.S. imports from low-wage economies since 1990 is dominated by China (Autor et al. 2012; Rigby et al. 2014), the differences in the low-wage country groupings are of little significance.

\subsection{Descriptive Statistics}

U.S. import competition overall increased from $16.7 \%$ to $24.8 \%$ over the period $1992-2007$. Over the same period, import competition from low-wage countries increased considerably faster (Rigby et al. 2014). Indeed, Autor et al. (2012) note that China alone was responsible for more than $90 \%$ of all growth in imports to the United States from low-wage countries between 2000 and 2007. Table 2 reports values of low-wage import competition for individual 3-digit NAICs 
sectors. In general, relatively low-skill, labor intensive sectors such as textile products, apparel and leather goods production have experienced the highest levels of low-wage import competition, though other industries with significant components of low-skill assembly activities, such as computer and electronics and electrical equipment manufacture as well as furniture production also compete in markets that are contested by low-wage countries. It is important to note that imports include the flow of goods from foreign affiliates of U.S. multinational corporations. Such imports are identified in the transaction-level trade data as flows between "related parties".

Manufacturing plant data from the Census of Manufactures in 1992, 1997, 2002 and 2007 are linked to measures of import competition for the same years. The import competition measures are defined at the 6-digit level of the NAICS classification, covering around 350 different manufacturing industries. Manufacturing plants are allocated to those same industrial sectors based on the composition of plant output by product. Plants are placed in the specific NAICS class that comprises the majority share of the plant's total value of output. Plant deaths or exits are captured when individual establishment identifiers disappear from the Longitudinal Business Database. Exits track real plant closures rather than changes of ownership.

By convention, the analytical samples exclude administrative record plants. These are relatively small, single-plant firms for which considerable data are imputed. Unlike Bernard et al. (2006), we do not drop NAICS sectors listed as "not elsewhere classified". These sectors typically contain miscellaneous plants that are not readily placed in other industrial classes. These NAICS classes are sometimes dropped because they prevent logit models from converging. This is not a problem in our models and our preference is to include all possible observations. Note that if we do exclude observations within these NAICS codes our model results do not change. In 1997, the Census did not collect information on capital investment in computers. This is a critical component of our measure of establishment-level technology. Rather than drop all data in 1997, we impute the missing capital investment variable as a simple average of values in surrounding years, or by setting it equal to the same variable in the prior or subsequent year of our sample if only one other establishment level observation was available. Plants in operation in year $t$ and $t+5$ that were not in operation in $t+10$ were defined as exits. Plants that remained in operation in $t+10$ are defined as incumbents. We identify two "spells" in our data. The first spell includes plants identified in 1992 that remain in operation in 1997. Our analysis explores whether these plants exited or not by 2002. Our second spell starts with plants in 1997 and that remain in operation in 2002. Analysis focuses on whether these plants exited by 2007. The overall plant exit rate between 1997 and 2002 and between 2002 and 2007 was approximately $27 \%$.

Table 3 displays the characteristics of incumbents and plant exits averaged over the two waves for which data are available. The differences reported are all statistically significant. In general, incumbent plants face lower import competition from both low-wage and high-wage countries, they have slightly higher TFP and computer investments, they are nearly twice as large as plants that exit, they exhibit higher levels of capital investment per worker and are slightly older. In addition, incumbent plants are significantly more likely to be exporters, to be part of a multi-unit firm and to have engaged in related-party trade with a foreign affiliate in a low-wage country. 


\section{Approach: Models of Plant Exit}

The models of exit developed in this section are driven by the differences in establishment characteristics reported in Table 3 . The models presented are of panel-form, that is they comprise both cross-sectional and longitudinal components. These models are estimated for two waves over three time periods 1992, 1997 and 2002 and 1997, 2002 and 2007 for reasons discussed below. To the best of our knowledge, these panel models are the first that focus on U.S. import competition and that incorporate plant-level fixed effects.

Most models linking imports to plant exit are essentially cross-sectional, taking plant, firm and industry characteristics in time period $t$ and relating those to the probability of plant exit in the time step between time period $t$ and $t+1$ (or $t+5$ in our case). While this specification is common, it does not take full advantage of all the possibilities in the data, particularly those that control for unobserved heterogeneity at the plant level. An example of a missing variable that might have serious impacts on a cross-sectional model of exit is managerial expertise. Unfortunately, no information about the skills of managers is available in the data we have access to, but it is clear that managerial expertise is likely to impact a number of plant-specific control variables that reflect choices of business owners/managers. Left unaccounted for, this correlation violates a key assumption of exogeneity and may result in biased and inconsistent estimators (Wooldridge 2002). We tackle this problem using a fixed effects panel model. With a binary dependent variable, an obvious choice in terms of estimation is the conditional logit model. Unfortunately, a lack of convergence in fixed effect panel logits estimated with maximum likelihood techniques meant that an alternative estimation strategy was required. In the end, we estimated our panel models of plant exit with the linear probability model. Use of the linear probability model (LPM) in settings where the dependent variable is binary raises some concerns. First, if LPM estimates fall outside the unit interval they are themselves likely to be biased and inconsistent. In the results we report below, this is not a problem. Second, LPM generates heteroscedasticity when the dependent variable is binary. To address this concern, all models are estimated using heteroscedasticity-consistent robust standard errors. It should be noted that use of the LPM in panel settings dampens the concerns just raised. Finally, our preliminary analysis with crosssectional logit models (not reported here) generated results similar to those already in the literature, and the results from our LPM panel models were qualitatively identical. We extend this discussion in Section 5.

To estimate our panel model of exit requires three consecutive time periods. Rather than explore the relationship between plant characteristics at time period $t$ and the probability of exit between $t$ and $t+5$, analysis in panel mode accounts for the probability of plant exit over the period $t+5$ to $t+10$, using changes in plant characteristics taken from periods $t$ and $t+5$. The four years of plant data thus constitute two waves in the panel model, the first covering the period 1992-2002 inclusive and the second covering the period 1997-2007 inclusive.

Building on models linking plant exit to import competition such as Bernard et al. (2006), Couke and Sleuwaegen (2008), Colantone et al. (2014), and the more general models of plant and firm exit (Dunne et al. 1989; Siegfried and Evans 1994; Baldwin and Gorecki 1998), we develop a composite econometric specification of manufacturing plant exit. Each wave of the panel takes the following form 


$$
\begin{aligned}
& \Delta \text { Exit }_{p}^{t+5 \rightarrow t+10}= \\
& \boldsymbol{\beta}_{m}^{\prime} \Delta \boldsymbol{P}_{m p}^{t \rightarrow t+5}+\boldsymbol{\beta}_{n}^{\prime} \Delta \boldsymbol{F}_{n p}^{t \rightarrow t+5}+\beta_{i} \Delta L O W_{-} W A G E_{-} I M P C O M P_{i}^{t \rightarrow t+5}+ \\
& \beta_{i} \Delta H I G H_{-} W A G E_{-} I M P C O M P_{i}^{t \rightarrow t+5}+\delta_{i}+\delta_{r}+\delta_{t}+\varepsilon_{p}
\end{aligned}
$$

where the $\Delta$ operator signifies the one period (5-year) difference in the following variable or vector of variables. The terms $\delta_{i}, \delta_{r}$ and $\delta_{t}$ represent industry, region and time-period fixed effects that are common to different dimensions of our panel data. These fixed effects are included in all model specifications. The dependent variable is binary, taking the value 0 for incumbents and 1 for establishments that exit. The vector $\boldsymbol{P}$ captures plant characteristics that change over the years $t$ to $t+5$ including the value of shipments (our measure of plant-size), the capital-labor ratio, relative plant age, the computer share of plant investment, plant-level exporting activity, total factor productivity, and whether the plant switches industry codes between $t$ and $t+5$. On the basis of the existing literature, we anticipate that older and larger plants, plants with higher levels of capital investment, particularly computer-related investment, plants with higher total factor productivity and plants that export should be less likely to exit. We expect that as plants alter the composition of their output and switch industries they will be less likely to exit. We augment these establishment variables with a vector of firm-level variables $\boldsymbol{F}$ that includes dummies indicating whether the plant is part of a multi-unit firm or part of a multinational firm that engages in related-party trade in a low-wage country. Bernard and Jensen (2007) suggest plants that are part of multi-unit firms have a higher probability of exit, along with plants that belong to U.S. multinational corporations. Finally, the key variable of interest is the $L O W \_W A G E I M P C O M P$, which captures industry-specific import competition from lowwage countries. As an additional control, we include the equivalent measure for imports from high-wage countries (HIGH_WAGE_IMPCOMP). We expect import competition from low wage countries to increase the likelihood of plant exit. Across most models standard errors are clustered by NAICS sector to guard against within cluster error correlation. For some models with instrumental variables we also report results where standard errors are not clustered. In all cases, standard errors are robust.

In the panel specification, the standard measure of plant age exhibits no cross-sectional variance over time since all plants age at the same pace. However, the difference between surviving from one period to the next for a plant that is only a year old and for a plant that is a decade old is not the same and we exploit this difference to capture the aging effect of plants on the probability of exit by measuring changes in relative plant age over time. The relative age of a plant is calculated by dividing the year $t$ by the year of birth of the plant. Thus, in the year 2005 a plant born in 1950 has the relative age $2005 / 1950=1.028205$. A plant born in 2000 has a relative age in 2005 equal to $2005 / 2000=1.0025$. By 2010, the relative age of the plant born in 1950 has increased to 1.030769 and the relative age of the plant born in 2000 has increased to 1.005 . Over the 5-year period between 2005 and 2010, the plant born in 1950 has aged in relative terms by $1.030769-1.028205=0.002564$ years. Over the same period, the plant born in 2000 has aged by $1.005-1.0025=0.0025$ years. The older plant has aged faster in relative terms. We would anticipate a negative effect of aging in our exit models. Those plants that age faster (older plants) should have a lower probability of exiting than younger plants. This is indeed what we see in the results. 
In contrast to some earlier models of plant/firm exit, we do not incorporate measures of skillintensity in our analysis. The primary reason for this is that such measures are unavailable and the proxy conventionally employed, the ratio of non-production to production workers, is very noisy. Concerns with use of this proxy are raised by Forbes (2001), Rigby and Breau (2008) and Ebenstein et al. (2009). We include a measure of the computer share of investment in our models and we anticipate that this variable will capture at least part of the influence of skill-intensity on plant exit.

Note that manufacturing plants in the first wave of the panel that remain in production through at least 2002 are present in both waves of the panel. In a second sample for equation 2, plants present in both waves of the panel were removed to insure the independence of all observations. The results were qualitatively similar and are not shown for brevity.

\section{Results: Estimates of Plant Exit}

This section describes results from a series of models that estimate the relationship between lowwage country import competition and plant exit. Table 4 presents our main results, with columns 1 and 2 reporting results that incorporate plant-level characteristics only and column 3 adding firm-level characteristics to those models. Table 5 presents initial results from instrumental variables estimates as we explore the robustness of the base results. Tables 6 and 7 enrich our understanding of the relationships between plant/firm characteristics and exit by exploring several dimensions of plant/firm heterogeneity in the data. In Table 6 we focus on multi-plant firms and explore whether the least productive establishment within the firm is the most likely to exit. Table 7 explores interactions between import competition and a series of plant/firm characteristics.

The essential relationship between low-wage country import competition and the likelihood of plant exit is explored in Table 4. Each column presents a slightly different model specification, fine-tuning our understanding of this relationship. We start with plant-level covariates only. Column one presents the most parsimonious model, reflecting the received understanding of import competition and plant exit. The key variable of interest is industry-specific low-wage country import competition. Increases in low-wage country import competition raise the likelihood of plant exit significantly, as expected. Import competition from high-wage countries also raises the probability of plant exit though the magnitude of this effect is much smaller. Consistent with much of the existing literature, including the work of Bernard et al. (2006), we report that larger plants, those that are older, that export, and that have higher investments in computing technology are less likely to exit. Higher levels of capital stock per worker had no significant influence on plant exit. Plants that switch industries, those that alter their mix of outputs perhaps in response to competitive pressure, are less likely to exit than are plants that remain in the same industry over time. Bernard et al. (2006) show, further, that switching plants adjust the composition of output their output to reduce their exposure to low-wage country imports.

We omit a productivity measure from the specification of model 1 as we expect that our plantlevel controls should capture much of the variance in plant survival that an independent productivity term would sweep up. A measure of plant-level total factor productivity (TFP) is 
added in model 2. Our intuition is not proved correct, for the TFP measure has an additional negative influence on the probability of plant-exit while leaving the influence of the other independent variables unchanged. Column 3 adds two firm-level controls to the model specification. First, a variable that captures the multi-plant status of firms shows that establishments that are part of multi-unit firms are more likely to exit than plants comprising single-unit firms. This finding is consistent with Bernard and Jensen (2007). Second, we add a flag indicating whether a plant is part of a firm that engages in related-party trade with an affiliate located in a low-wage country. Our intuition is that multi-national firms operating in low-wage countries can more readily offshore tasks that might duplicate the imports from lowwage competitors and thus the plants of such firms should have a lower probability of exit. The results are consistent with this argument. Bernard and Jensen (2007) report that plant exit is higher for units of multi-national firms. Our results suggest that more work is required to characterize the nature of foreign affiliates and what role those affiliates might play in the strategies of multi-nationals.

In Table 5 attention turns to simultaneity bias and the potential endogeneity of our measure of low-wage import competition. We instrument for this variable using estimates of import competition for European Union manufacturing sectors in similar fashion to Autor et al. (2012). In column 1 of Table 5 we show results of our non-instrumented model to facilitate comparison with the instrumental variables estimates that are displayed in columns 2 and 3 of the table. In the IV model results reported in column 2 standard errors are not clustered, while in the IV model results reported in column 3 standard errors are clustered by NAICS sectors. The first stage diagnostics from the instrumental variable regressions are reported at the bottom of the table. The Kleinbergen-Paap rk LM-statistics for the first-stage regressions reported in columns 2 and 3 both lead to rejection of the null hypothesis that the matrix of reduced form coefficients is under-identified. The Cragg-Donald and Kleibergen-Paap F-statistics for weak instruments reported are both above the Stock-Yogo critical threshold of 10. The sharp decline in the value of the Kleibergen-Paap F-statistic for weak instruments in column 3 is a reflection of the use of clustered standard errors in this model, though the standard Stock-Yogo threshold is still passed. Unfortunately with only one instrumental variable, over-identification tests cannot be performed. We did attempt to employ a second instrument, an estimate of trade costs (see Bernard et al. 2006) that we have successfully employed elsewhere (Kemeny et al. 2015). However, the tradecost instrument proved very weak either on its own or alongside the EU measure of import competition, failing first-stage F-tests, and so we abandoned use of this second instrument.

In a qualitative sense, the results from the models where we instrument for low-wage import competition are virtually indistinguishable from those where we do not instrument. The signs and significance of the independent variables are consistent across both sets of models. However, the coefficients for our instrumented measure of low-wage import competition increase by about an order of magnitude over the non-instrumented model. In general, there are two primary concerns with IV estimates, that they are weak or that the standard exclusion restriction is invalid. As noted above, we pass the standard tests for weak instruments and the exclusion restriction cannot directly be tested. Again we might take some solace in our panel specification that reduces the likelihood that our instrument might be correlated with an omitted variable. It turns out, that Bernard et al. (2006) report similar findings in their analysis of plant exit, even though they use a quite different instrument. At this point, perhaps, we can safely agree that low-wage import 
competition hastens plant exit, though the precise magnitude of that effect awaits further investigation.

Next, we turn attention to further exploration of the role of plant heterogeneity in mediating the impact of low-wage country import competition on plant exit. Building on the findings in Table 4, we expect that the increased likelihood of exit for plants that are part of a multi-unit firm is not distributed evenly across all establishments of a single firm. To explore this possibility we limit our analytical sample to plants that are part of multi-unit firms and we construct a dummy variable to identify the plant with the lowest productivity (TFP) within each firm. We hypothesize that the probability of exit for such plants should be higher than average. The results from re-estimating equation 2 for this restricted multi-unit firm sample are presented in Table 6.

Estimating equation 2 using the linear probability model (LPM) and starting with plant-level controls only, column 1 presents a model that includes the flag for the lowest productivity plant, but no overall TFP measure. Column 2 presents the same model, but includes our measure of plant productivity (TFP). Column 3 adds the remaining firm-level variable, related party trade in a low-wage country. In all these models there is strong consistency in the results. Low-wage country import competition remains positive and significant, raising the likelihood of plant exit. While estimates of the coefficients on our control variables are broadly consistent with the results already presented, the coefficient that captures switching plants, those that alter their product mix and change industries, reverses sign in these models. Thus, switching plants are more likely to exit than are than non-switching plants in our multi-unit firm sample. The significance of this relationship disappears in the IV models of Table 6 (columns 4 and 5), that otherwise tell a markedly consistent story. Of most interest in Table 6, and consistent across all specifications, is the result for the dummy indicating the least productive plant within each firm. In all cases, the coefficient on the dummy is positive and significant at the one percent level. This result is consistent with the idea that as firms face increasing import competition (in some or all of their activities), multi-unit firms respond by closing their least productive sites, shifting attention and resources to other parts of the firm. This reallocation of resources between plants within the multi-unit firm is consistent with the findings of Bloom et al. (2011) on between firm shifts in Europe.

Finally we turn our attention to a series of interactions, in which we explore how our main relationship of interest - between plant exit and changes in low wage import competition - may itself depend on a host of other plant characteristics. Taking the example of total factor productivity, we are interested in describing whether the odds of trade-induced plant exit vary according to a plant's productivity. We explore such interactions for individual variables and for all variables together. If a variable yielded no significant interaction and was unchanged in its individual effect it was not interacted with import competition in the results shown in Table 7. This was the case for firm-size, related party trade in a low-wage country and the computer share of investment. The other variables were interacted with low-wage import competition. Table 7 presents three models of such interactions, the first (column 1) ignoring concerns with endogeneity and the next two (columns 2 and 3 ) incorporating our instrument for low-wage import competition. In the latter case, the instruments for the interaction terms were built as the product of the original independent variables and the EU import competition instrument. 
Column 1 of Table 7 reports results of our standard model with interactions between plant and firm characteristics, without instrumenting for low-wage import competition. In non-interacted form, the independent variables behave as previously reported, save for the influence of the capital-labor ratio that now becomes significant, though only at the 0.1 level. As we examine the interactions in column 1, we start with those plant and firm variables that are categorical. First, the results show that whether or not plants switch industries, differences in the probability of exit linked to increasing low-wage import competition are not significant. Second, plants that are part of multi-unit firms have exit probabilities that rise faster than those for single-plant firms when import competition from low-wage countries increases. Third, plants that export face smaller increases in the probability of exit than non-exporting plants as import competition intensifies. Turning to the continuous variable interactions, the change in the probability of plant exit with increased low-wage import competition is significantly lower for more productive plants than it is for less productive plants. Variations in capital-labor ratios across plants have no significant influence on changes in the probability of exit as low-wage import competition increases.

Shifting to columns 2 and 3 of Table 7 we incorporate instrumental variables in these interaction models. Once more our models pass the standard tests for identification and weak instruments. Results for the interactions between exporting plants and import competition and between plant productivity levels and import competition do not change. However, for all other interactions there are important differences between the instrumented and non-instrumented model results. Perhaps most importantly, after instrumenting, we see that the change in the probability of exit induced by higher levels of low-wage import competition is smaller for plants that are part of multi-unit firms than for single-plant firms. In similar fashion, the interaction model shows that there are significant differences in the partial regression slope coefficients for the impact of lowwage import competition on plant exit for plants that do or do not switch industries and for plants with different capital-labor ratios. These results are consistent across the models whether standard errors are clustered or not. Overall, the findings in Table 7 suggest that heterogeneity between manufacturing establishments has a more complex impact on the relationship between low-wage import competition and plant exit than previously thought.

\section{Conclusion}

Building on a resurgence of interest on the labor market impacts of international trade in highwage countries, this paper examines how import competition from low-wage countries influences manufacturing plant exit in the United States. To do this, we combine U.S. manufacturing plant-level data spanning the period 1992-2007 with firm-level data and with measures of low-wage import competition by detailed industry group. We report results from a series of linear probability models estimated in fixed effects panel form. Our core specification adopts a three period panel that allows us to control for unobserved heterogeneity at the plant level in our models of plant exit. This represents a significant advance over existing models of trade competition and exit. We update past estimates of low-wage country import competition and plant exit and we extend those models to explore the influence of different forms of plant and firm heterogeneity on the likelihood of plant closure. An instrumental variables approach is employed to examine whether or not the core results are robust to concerns regarding endogeneity. 
Controlling for unobserved heterogeneity at the plant level in a series of linear probability models estimated over two three-year panels (1992-1997-2002 and 1997-2002-2007) we generate a series of results that are broadly consistent with existing research, notably that of Bernard et al. (2006). Plant-size and relative plant age are inversely related to the probability of exit. Manufacturing plants that are more capital-intensive and that direct higher shares of capital investment into computing technology are also less likely to exit. These effects are statistically significant. We found no influence of the capital to labor ratio within plants on the probability of establishment closure. Plants with higher total factor productivity were significantly more resistant to exit. We also find that manufacturing plants that alter the product composition of their output such that they are reclassified from one 6-digit NAICS class to another are less likely to exit. This finding supports earlier work that suggests product switching is a strategic response to import competition from low-wage countries. Turning to trade, across all models, rising import competition is positively associated with plant exit. This effect is always statistically significant. We build measures of import competition from low-wage countries and high-wage countries. Including both measures in our models, the influence of low-wage import competition on establishment closure is always more than two orders of magnitude greater than the influence of high-wage import competition.

As we add firm-level characteristics to our models we update and confirm some of the findings of Bernard and Jensen (2007) while extending the analysis and making it robust to unobserved plant-level heterogeneity. Our results show that plants which are part of multi-unit firms have significantly higher probabilities of exit than single-plant firms. Further, we use an instrumental variables approach to show that this effect is robust to concerns regarding the endogeneity of our measure of low-wage import competition. While Bernard and Jensen (2007) also report that plants belonging to multi-national firms have a higher probability of exit than plants which are not affiliated with multi-national firms, we show that if a plant is part of a firm that engages in related-party trade with a foreign affiliate in a low-wage country then the plant has a lower probability of exit than one that is not part of a firm engaged in the same trade relationship. We suspect that multi-national firms operating in low-wage countries can more readily offshore tasks that might duplicate the imports from low-wage competitors and thus the plants of such firms are to some degree inured from such competition. The geography of firm-level related-party affiliations matters for plant exit.

Exploring various dimensions of plant heterogeneity in our data, we are also able to show that the least productive plants in multi-plant firms are the most likely establishments to be forced from the market. Further, low-wage country import competition interacts significantly with a number of plant-level and firm-level characteristics that shape the probability of manufacturing plant exit. In particular, establishments that are part of multi-unit firms have exit probabilities that rise faster than those for single-plant firms when import competition from low-wage countries increases. At the same time, plants that export and more productive plants face smaller increases in the probability of exit than non-exporting plants less productive units as import competition intensifies. Finally, we find that the change in the probability of exit induced by higher levels of low-wage import competition is smaller for plants that are part of multi-unit firms than for single-plant firms. These explorations of establishment heterogeneity suggest a lot more analysis is necessary to understand the linkages between the strategic decisions of different kinds of plants and firms and the nature of trade-based competition. 
Concern with the potential endogeneity of our measure of low-wage import competition in the U.S. prompted us to utilize an instrumental variables approach. As an instrument, we used lowwage import competition for a number of European Union countries. Estimating panel models using instrumental variables (IV) approaches had no qualitative impact on our core results, though IV estimates of the partial regression coefficient linking import competition to plant exit increased roughly by an order of magnitude over the OLS results. This mirrors the earlier analysis of Bernard et al. (2006). Additional research is clearly required to provide more precise and robust point estimates of the impact of foreign competition on manufacturing plant death.

Finally, it is clear from Autor et al. (2012) and Rigby et al. (2014) that Chinese exports have been the primary driver of the rise in U.S. import competition originating from low-wage countries over the last two decades or so. Whether imports from China are of a fundamentally different character than imports from other low-wage countries is a matter of some debate (Mion and Zhu 2013). Clearly, separating imports from different countries, low-wage and high-wage, and examining their individual impact on the U.S. economy would be of considerable interest. 


\section{Acknowledgements}

This research was supported by the National Science Foundation under grant number BCS0961735. The authors would like to acknowledge comments by a referee that significantly improved the quality of this manuscript. 


\section{Bibliography}

Alvarez, R. and S. Claro 2009. David vs. Goliath: The impact of Chinese competition on developing countries. World Development 37: 560-571.

Alvarez, R. and S. Vergara 2010. Exit in developing countries: Economic reforms and plant heterogeneity. Economic Development and Cultural Change 58: 537-561.

Amiti, M. and J. Konigs 2007. Trade liberalization, intermediate inputs, and productivity: Evidence from Indonesia. American Economic Review 97: 1611-1638.

Antras, P. and E. Helpman 2004. Global sourcing. Journal of Political Economy 112: 552-580.

Antras, P. and E. Rossi-Hansberg 2008. Organizations and trade. NBER Working Paper \#14262.

Arvis, J.F., Duval, Y., Shepherd, B., Utoktham, C. and A. Raj (2016) Trade costs in the developing world: 1996-2010. World Trade Review 15: 451-474.

Autor, D.,Dorn, D. and G. Hanson 2012. The China syndrome: Local labor market effects of import competition in the United States. NBER Working Paper \#18054.

Autor, D., Dorn, D. and G. Hanson 2013. Untangling trade and technology: Evidence from local labor markets. NBER Working Paper \#18938.

Aw, B. and A. Hang 1995. Productivity and the export market: A firm-level analysis. Journal of Development Economics XLVII: 277-297.

Baldwin, R. 2006. Globalisation: the great unbundling(s). Finnish Prime Minister's Office for EU Presidency.

Baldwin, J. and P. Gorecki 1998. The Dynamics of Industrial Competition: A North American Perspective. Cambridge: Cambridge University Press.

Baldwin, J. and B. Yan 2011.The death of Canadian manufacturing plants: heterogeneous responses to changes in tariffs and real exchange rates. Review of World Economics 147: 131167.

Bandick, R. 2010. Multinationals and plant survival. Review of World Economics 146: 609-634.

Bas, M. and V. Strauss-Kahn 2014. Does importing more inputs raise exports? Firm-level evidence from France. Review of World Economics 150: 241-275.

Berman. E., Bound, J. and Z. Griliches 1994. Changes in the demand for skilled labor within U.S. manufacturing: Evidence from the Annual Survey of Manufacturers. Quarterly Journal of Economics 109: 367-397. 
Bernard, A. Eaton, J., Jensen, J. and S. Kortum 2003. Plants and productivity in international trade. American Economic Review 93: 1268-1290.

Bernard, A. and J. Jensen 1999. Exceptional exporter performance: cause, effect, or both? Journal of International Economics 47: 1-25.

Bernard, A., and J. Jensen 2007. Firm structure, multinationals, and manufacturing plant deaths. Review of Economics and Statistics 89: 193-204.

Bernard, A., J. Jensen and P. Schott 2006. Survival of the best fit: Exposure to low-wage countries and the (uneven) growth of US manufacturing plants. Journal of International Economics 68: 219-237.

Bernard, A., Redding, S. and P. Schott 2011. Multiproduct firms and trade liberalization. Quarterly Journal of Economics 126: 1271-1318.

Blinder, A. 2006. Offshoring: the next industrial revolution. Foreign Affairs 85: 113-128.

Bloom, N., Draca, M. and J. Van Reenen 2011. Trade induced technical change? The impact of Chinese imports on innovation, IT and productivity. NBER Working Paper 16717.

Castellani, D., Serti, F. and C. Tomasi 2010. Firms in international trade: Importers' and exporters' heterogeneity in Italian manufacturing industry. The World Economy 33:424-457.

Clerides, S., Lack, S. and J. Tybout 1998. Is learning by exporting important: Micro-dynamic evidence from Colombia, Mexico, and Morroco. Quarterly Journal of Economics 113: 903-947.

Colantone, I., Coucke, K. and L. Sleuwaegen 2014. Low-cost import competition and firm-exit: Evidence from the EU. Industrial and Corporate Change doi: 10.1093/icc/dtu008.

Colantone, I., \& Sleuwaegen, L. (2010). International trade, exit and entry: A cross-country and industry analysis. Journal of International Business Studies 41: 1240-1257.

Coucke, K. and L. Sleuwaegen 2008. Offshoring as a survival strategy: Evidence from manufacturing firms in Belgium. Journal of International Business Studies 39: 1261-1277.

Djankov, S., Freund, C. and C. Pham (2010) Trading on time. The Review of Economics and Statistics 92: 166-173.

Dunne, T., Roberts, M. and L. Samuelson 1989. Patterns of firm entry and exit in U.S. manufacturing industries. RAND Journal of Economics 19: 495-515.

Easterly, W. (2005) What did structural adjustment adjust? The association of policies and growth with repeated IMF and World Bank adjustment loans. Journal of Development Economics 76: 1-22. 
Eaton, J., Kortum, S. and F. Kramarz 2008. An anatomy of international trade: Evidence from French firms. NBER Working Paper \#14610.

Ebenstein, A., Harrison, A., McMillan, M., Phillips, S., and Hall, G. 2009. Estimating the Impact of Trade and Offshoring on American Workers Using the Current Population Surveys. NBER Working Paper No. 15107.

Eriksson, T. Smeets, V. and F. Warzynski 2009. Small open economy firms in international trade: Evidence from Danish transactions data. Working Paper 09-7. Aarhus School of Business, University of Aarhus.

Eslava, E., Haltiwanger, J., Kugler, A. and M. Kugler 2013. Trade and market selection: Evidence from manufacturing plants in Colombia. Review of Economic Dynamics 16: 135-158.

Esteve-Perez, S., Manez-Castillejo, J. and J. Sanchis-Llopis 2008. Does a "survival by exporting" effect for SMEs exist? Empirica 35: 81-104.

Feenstra, R. 2008. Offshoring in the global economy. The Ohlin Lectures, Stockholm School of Economics.

Feenstra, R. and G. Hanson 1996. Globalization, outsourcing, and wage inequality. American Economic Review 86: 240-245.

Feenstra, R. and G. Hanson 2001. Global production sharing and rising inequality: a survey of trade and wages. NBER Working Paper No. 8372.

Forbes, K. 2001. Skill classification does matter: estimating the relationship between trade flows and wage inequality. Journal of Trade and Development 10: 175-209.

Freund, C. (2009) The trade response to global downturns: historical evidence. World Bank Policy Research Working Paper Series, Vol (2009).

Gibson, J. and R. Harris 1996. Trade liberalization and plant exit in New Zealand manufacturing. Review of Economics and Statistics 78:521-529.

Gorg, H. and M. Spaliara 2010. Financial health, exports and firm survival: A comparison of British and French firms. Kiel Working Paper \#1568. Kiel: Kiel Institute for the World Economoy.

Greenaway, D. and R. Kneller 2007. Firm heterogeneity, exporting and foreign direct investment. The Economic Journal 117: F134-F161.

Greenaway, D., Gullstrand, J. and R. Kneller 2008. Surviving globalisation. Journal of International Economics 74: 264-277. 
Head, K. and J. Ries 2003. Heterogeneity and the FDI versus export decision of Japanese manufacturers. Journal of Japanese International Economics 17: 448-467.

Helpman, E., Melitz, M. and S. Yeaple 2004. Export versus FDI with heterogeneous firms. American Economic Review 94: 300-316.

Hummels, D., Jorgenson, R., Munch, J. and C. Xiang 2014. The wage and employment effects of outsourcing: Evidence from Danish matched worker-firm data. American Economic Review 104: $840-870$.

Inui, T., Kneller, R., Matsuura, T. and D. McGowan 2009. Globalization, productivity and plant exit - evidence from Japan. RIETI Discussion Paper Series 09-E-048.

Kemeny, T., Rigby, D. and A. Cooke 2015. Cheap imports and the loss of U.S. manufacturing jobs. The World Economy DOI: 10.1111/twec.12238.

Kletzer, L. 2002. Imports, Exports, and Jobs. Kalamazoo: Upjohn Institute for Employment Research.

Lawrence, R. and M. Slaughter 1993. Trade and US wages: Great sucking sound or small hiccup? Brookings Papers on Economic Activity, Microeconomics. Washington DC: Brookings Institution, 161-211.

Lileeva, A. 2008. Trade liberalization and productivity dynamics: Evidence from Canada. Canadian Journal of Economics 41: 360-390.

Lopez, R. 2006. Imports of intermediate inputs and plant survival. Economics Letters 92: 58-62.

Melitz, M. 2003. The impact of trade on intra-industry reallocations and aggregate industry productivity. Econometrica 71: 1697-1725.

Mion, G. and L. Zhu 2013. Import competition from and offshoring to China: A curse or blessing for firms? Journal of International Economics 89: 202-215.

Pavcnik, N. 2002. Trade liberalization, exit, and productivity improvements: Evidence from Chilean plants. Review of Economic Studies 69: 245-276.

Pierce, J. and P. Schott 2012. The surprisingly swift decline of U.S. manufacturing employment. NBER Working Paper \#18655. National Bureau of Economic Research, Cambridge, MA.

Rigby, D.L. and S. Breau 2008. Impacts of trade on wage inequality: A case study of Los Angeles using matched employer-employee data. Annals of the Association of American Geographers 98: 920-940.

Rigby, D.L., Kemeny, T. and A, Cooke 2014. Impact of trade with low-wage countries on U.S. wage inequality. Tijdschrift voor Economische en Sociale Geografie 106: 570-587. 
Sachs, J. and H. Schatz 1994. Trade and jobs in US manufacturing. Brookings Papers on Economic Activity. Washington, DC: Brookings Institution, 1-84.

Siegfried, J. and L. Evans 1994. Empirical studies of entry and exit: a survey of the evidence. Review of Industrial Organization 9: 121-155.

Vogel, A. and J. Wagner 2010. Higher productivity in importing German manufacturing firms: Self-selection, learning from importing, or both? Review of World Economics 145: 641-665.

Wagner, J. 2007. Exports and productivity: A survey of the evidence from firm-level data. The World Economy 30: 60-82.

Wooldridge, J. 2002. Econometric Analysis of Cross Section and Panel Data. Cambridge, MA: MIT Press.

Yeaple, S. 2005. A simple model of firm heterogeneity, international trade, and wages. Journal of International Economics 65: 1-20. 
Table 1: List of Low-Wage Countries, World Bank 1992

\begin{tabular}{|l|l|l|l|l|l|}
\hline Afghanistan & Bangladesh & Bhutan & Benin & Burkina Faso & Burundi \\
\hline Cambodia & $\begin{array}{l}\text { Central African } \\
\text { Republic }\end{array}$ & Chad & China & Comoros & Congo \\
\hline Egypt & Equatorial Guinea & Ethiopia & Gambia & Ghana & Guinea \\
\hline Guinea-Bissau & Guyana & Haiti & Honduras & India & Indonesia \\
\hline Kenya & Laos & Lesotho & Liberia & Madagascar & Malawi \\
\hline Maldives & Mali & Mauritania & Mozambique & Myanmar & Nepal \\
\hline Niger & Nigeria & Pakistan & Rwanda & Sao Tome & Sierra Leone \\
\hline Solomon Is. & Somalia & Sri Lanka & Sudan & Tanzania & Togo \\
\hline Uganda & Vietnam & Zambia & & & \\
\hline
\end{tabular}


Table 2: Low-Wage Country Import Competition

\begin{tabular}{llllll}
\hline NAICS & Manufacturing Industry & \multicolumn{4}{c}{ LWC Import Competition } \\
& & 1992 & 1997 & 2002 & 2007 \\
\hline 311 & Food & 0.4 & 0.5 & 0.5 & 1.1 \\
312 & Beverage \& Tobacco & 0.0 & 0.2 & 0.2 & 0.2 \\
313 & Textile Mills & 3.2 & 3.5 & 5.2 & 8.5 \\
314 & Textile Products & 8.6 & 7.7 & 14.1 & 32.8 \\
315 & Apparel & 16.4 & 21.0 & 28.2 & 57.5 \\
316 & Leather & 28.2 & 42.3 & 58.4 & 70.3 \\
321 & Wood & 1.7 & 1.6 & 2.1 & 3.8 \\
322 & Paper & 0.2 & 0.4 & 0.9 & 2.1 \\
323 & Printing \& Related & 2.2 & 1.7 & 5.3 & 14.2 \\
324 & Petroleum \& Coal & 0.4 & 1.3 & 0.8 & 0.6 \\
325 & Chemicals & 0.4 & 0.7 & 0.9 & 1.8 \\
326 & Plastics \& Rubber & 0.8 & 1.6 & 2.8 & 6.1 \\
327 & Non-Metallic Minerals & 1.4 & 2.6 & 4.5 & 6.3 \\
331 & Primary Metals & 0.6 & 0.8 & 1.4 & 3.8 \\
332 & Fabricated Metals & 1.1 & 1.6 & 3.5 & 6.9 \\
333 & Machinery & 0.6 & 1.4 & 2.8 & 6.4 \\
334 & Computer \& Elec & 2.1 & 3.6 & 9.3 & 23.1 \\
335 & Electrical Equipment & 2.9 & 5.3 & 10.1 & 16.5 \\
336 & Transport Equipment & 0.1 & 0.2 & 0.5 & 1.7 \\
337 & Furniture & 1.5 & 4.0 & 11.1 & 19.9 \\
339 & Miscellaneous & 10.5 & 14.4 & 17.7 & 26.0 \\
\hline
\end{tabular}

Notes: LWC Import Competition measures are shown as percentages. 
Table 3: Characteristics of Manufacturing Plants (Exit and Incumbents, all years)

\begin{tabular}{|c|c|c|c|}
\hline Variable & Incumbents & Exits & $t$-statistic \\
\hline Low-Wage Import Competition & $\begin{array}{c}0.027 \\
(0.000)\end{array}$ & $\begin{array}{c}0.035 \\
(0.000)\end{array}$ & -18.517 \\
\hline High-Wage Import Competition & $\begin{array}{c}0.131 \\
(0.005)\end{array}$ & $\begin{array}{c}0.171 \\
(0.013)\end{array}$ & -2.907 \\
\hline Log of Total Factor Productivity & $\begin{array}{c}1.987 \\
(0.002)\end{array}$ & $\begin{array}{c}1.942 \\
(0.003)\end{array}$ & 14.468 \\
\hline Computer Share of Investment & $\begin{array}{c}0.108 \\
(0.001)\end{array}$ & $\begin{array}{c}0.089 \\
(0.001)\end{array}$ & 20.402 \\
\hline Industry Switcher & $\begin{array}{c}0.132 \\
(0.001)\end{array}$ & $\begin{array}{c}0.125 \\
(0.002)\end{array}$ & 3.838 \\
\hline Value of Shipments & $\begin{array}{c}24978 \\
(441)\end{array}$ & $\begin{array}{l}14217 \\
(483)\end{array}$ & 16.451 \\
\hline Capital-Labor Ratio & $\begin{array}{l}79.387 \\
(0.653)\end{array}$ & $\begin{array}{l}68.015 \\
(2.094)\end{array}$ & 5.184 \\
\hline Relative Age & $\begin{array}{c}1.008 \\
(0.000)\end{array}$ & $\begin{array}{c}1.007 \\
(0.000)\end{array}$ & 28.703 \\
\hline Exports Dummy & $\begin{array}{c}0.283 \\
(0.001)\end{array}$ & $\begin{array}{c}0.182 \\
(0.002)\end{array}$ & 44.824 \\
\hline Multi-Unit Dummy & $\begin{array}{c}0.340 \\
(0.001)\end{array}$ & $\begin{array}{c}0.315 \\
(0.002)\end{array}$ & 9.563 \\
\hline Low-Wage Country Related Party Trade & $\begin{array}{c}0.016 \\
(0.000)\end{array}$ & $\begin{array}{c}0.011 \\
(0.000)\end{array}$ & 8.567 \\
\hline
\end{tabular}

Notes: The terms in parentheses represent standard errors. t-statistics were obtained through ANOVA with year fixed effects. All values refer to means for the two plant types. LOW_WAGE_IMPCOMP is the measure of lowwage country import competition for the industry in which the plant is located, HIGH_WAGE_IMPCOMP is the equivalent measure of import competition but from high-wage countries, LN(TFP) is a plant specific estimate of TFP, COMPUTER_SHARE represents the share of investments devoted to computers and related equipment, IND_SWITCHER is a dummy variable marking whether a plant switched NAICS industry codes between period $t$ and period $t+5$, TVS is the total value of shipments, $\mathrm{KL}$ is the capital-labor ratio, RELATIVE_AGE is a measure of plant age (year/plant birth year), EXPORTS_DUMMY indicates whether the plant had non-zero exports, MULTI_UNIT refers to the share of plants that belong to a multi-unit firm, LOW_WAGE_RELATED_TRADE denotes whether the plant is part of multi-national firm trading with a foreign affiliate located in a low-wage country. 
Table 4: Low-Wage Import Competition and Plant Exit, Panel Estimation: Linear Probability Models (OLS)

(1)

(3)

Plant-level controls only

Firm-controls

\begin{tabular}{lccc} 
Variable & No TFP & With TFP & \\
\hline Low-Wage Import Competition & $0.2865^{* *}$ & $0.2813^{* *}$ & $0.2854^{* *}$ \\
High-Wage Import Competition & $(0.1141)$ & $(0.1139)$ & $(0.1139)$ \\
& $0.0019^{* * *}$ & $0.0019^{* * *}$ & $0.0019^{* * *}$ \\
Computer Share of Investment & $(0.0004)$ & $(0.0004)$ & $(0.0004)$ \\
& $-0.2136^{* * *}$ & $-0.2135^{* * *}$ & $-0.2137^{* * *}$ \\
Industry Switcher & $(0.0162)$ & $(0.0162)$ & $(0.0162)$ \\
& $-0.0347^{* * *}$ & $-0.0341^{* * *}$ & $-0.0344^{* * *}$ \\
Value of Shipments & $(0.0061)$ & $(0.0061)$ & $(0.0061)$ \\
& $-1.48 \mathrm{e}-07^{* * *}$ & $-1.41 \mathrm{e}-07^{* * *}$ & $-1.41 \mathrm{e}-07^{* * *}$ \\
Capital-Labor Ratio & $(4.14 \mathrm{e}-08)$ & $(3.91 \mathrm{e}-08)$ & $(3.89 \mathrm{e}-08)$ \\
& -0.00002 & -0.00002 & -0.00002 \\
Relative Age & $(0.00001)$ & $(0.00001)$ & $(0.00001)$ \\
& $-2,813.71^{* * *}$ & $-2,823.79^{* * *}$ & $-2,811.45^{* * *}$ \\
Exports Dummy & $(256.5)$ & $(255.3)$ & $(255.7)$ \\
& $-0.0333^{* * *}$ & $-0.0324 * * *$ & $-0.0323^{* * *}$ \\
Log TFP & $(0.0031)$ & $(0.0031)$ & $(0.0031)$ \\
& & $-0.0253^{* * *}$ & $-0.0253^{* * *}$ \\
Multi-Unit Dummy & & $(0.0042)$ & $(0.0042)$ \\
Low-Wage Country Related Party & & & $0.0172^{* *}$ \\
Trade & & & $(0.0087)$ \\
& & & $-0.049^{* * *}$ \\
Observations & & & $(0.0103)$ \\
R-squared & 0.26 & 330000 \\
\hline Not N & & 0.26 \\
\hline
\end{tabular}

Notes: Numbers of observations have been rounded to protect confidentiality of respondents. All models include industry, region and year fixed effects and robust standard errors. Standard errors are clustered by NAICS. * indicates significance at the 0.1 level, ** at the 0.05 level and *** at the 0.01 level. 
Table 5: Low-Wage Import Competition and Plant Exit Panel Estimation: Instrumental Variables (IV) Approach

\begin{tabular}{|c|c|c|c|}
\hline & (1) & (2) & (3) \\
\hline Variable & $\begin{array}{l}\text { OLS - without high- } \\
\text { wage impcomp }\end{array}$ & $\begin{array}{l}I V-\text { no } \\
\text { clustering }\end{array}$ & $I V$ - cluster by NAICS \\
\hline \multirow[t]{2}{*}{ Low-Wage Import Competition } & $0.2871 * *$ & $2.9103^{* * *}$ & $2.9103 * * *$ \\
\hline & $(0.1138)$ & $(0.2123)$ & $(1.0442)$ \\
\hline \multirow[t]{2}{*}{ Computer Share of Investment } & $-0.2138 * * *$ & $-0.2027 * * *$ & $-0.2027 * * *$ \\
\hline & $(0.0162)$ & $(0.0108)$ & $(0.0150)$ \\
\hline \multirow[t]{2}{*}{ Industry Switcher } & $-0.0344 * * *$ & $-0.037 * * *$ & $-0.037 * * *$ \\
\hline & $(0.0061)$ & $(0.0065)$ & $(0.0100)$ \\
\hline \multirow[t]{2}{*}{ Value of Shipments } & $-1.41 \mathrm{e}-07 * * *$ & $-1.14 \mathrm{e}-07 * * *$ & $-1.14 \mathrm{e}-07 * * *$ \\
\hline & $(3.89 \mathrm{e}-08)$ & $(2.74 \mathrm{e}-08)$ & $(4.28 \mathrm{e}-08)$ \\
\hline \multirow[t]{2}{*}{ Capital-Labor Ratio } & -0.00001 & $-5.53 e-06$ & $-5.53 e-06$ \\
\hline & $(0.00001)$ & $(0.00001)$ & $(0.00001)$ \\
\hline \multirow[t]{2}{*}{ Relative Age } & $-2,809.81^{* * *}$ & $-2,296.37 * * *$ & $-2,296.37 * * *$ \\
\hline & $(255.6)$ & $(212.7)$ & $(320.3)$ \\
\hline \multirow[t]{2}{*}{ Exports Dummy } & $-0.0324 * * *$ & $-0.0302 * * *$ & $-0.0302 * * *$ \\
\hline & $(0.0031)$ & $(0.0038)$ & $(0.0042)$ \\
\hline \multirow[t]{2}{*}{ Log TFP } & $-0.0253 * * *$ & $-0.0291 * * *$ & $-0.0291 * * *$ \\
\hline & $(0.0042)$ & $(0.0040)$ & $(0.0060)$ \\
\hline \multirow[t]{2}{*}{ Multi-Unit Dummy } & $0.0172 * *$ & $0.0209 * *$ & $0.0209 * *$ \\
\hline & $(0.0087)$ & $(0.0092)$ & $(0.0103)$ \\
\hline \multirow[t]{2}{*}{ Low-Wage Country Related Party Trade } & $-0.0488 * * *$ & $-0.0627 * * *$ & $-0.0627 * * *$ \\
\hline & $(0.0103)$ & $(0.0106)$ & $(0.0123)$ \\
\hline Observations & 330000 & 130000 & 130000 \\
\hline R-squared & 0.26 & - & - \\
\hline Kleinbergen-Paap rk LM statistic & - & 1701.9 & 15.5 \\
\hline Cragg-Donald Wald F-statistic & - & 5581.5 & 5581.5 \\
\hline Kleinbergen-Paap Wald F statistic & - & 1713.9 & 13.6 \\
\hline
\end{tabular}

Notes: Numbers of observations have been rounded to protect confidentiality of respondents. All models include industry, region and year fixed effects and robust standard errors. * indicates significance at the 0.1 level, ** at the 0.05 level and $* * *$ at the 0.01 level. 
Table 6: Low-Wage Import Competition and Plant Exit Panel Estimation: Lowest Productivity Plants within Multi-Unit firms

\begin{tabular}{|c|c|c|c|c|c|}
\hline & (1) & (2) & (3) & (4) & (5) \\
\hline Variable & $\begin{array}{c}\text { LPM - } \\
\text { Without TFP }\end{array}$ & $\begin{array}{c}\text { LPM - } \\
\text { With TFP }\end{array}$ & $\begin{array}{c}\text { LPM - } \\
\text { LDC Related } \\
\text { Party Trade }\end{array}$ & $\begin{array}{c}I V-n o \\
\text { clustering }\end{array}$ & $\begin{array}{c}I V-\text { cluster by } \\
\text { NAICS }\end{array}$ \\
\hline $\begin{array}{l}\text { Low-Wage } \\
\text { Import Competition }\end{array}$ & $\begin{array}{c}0.6403 * * * \\
(0.1420)\end{array}$ & $\begin{array}{c}0.6379 * * * \\
(0.1402)\end{array}$ & $\begin{array}{c}0.6479 * * * \\
(0.1398)\end{array}$ & $\begin{array}{l}2.664 * * * \\
(0.3446)\end{array}$ & $\begin{array}{l}2.664 * * * \\
(0.8163)\end{array}$ \\
\hline $\begin{array}{l}\text { Lowest Productivity } \\
\text { Plant in Firm }\end{array}$ & $\begin{array}{c}0.0385 * * * \\
(0.0057)\end{array}$ & $\begin{array}{c}0.0358 * * * \\
(0.0059)\end{array}$ & $\begin{array}{c}0.0357 * * * \\
(0.0059)\end{array}$ & $\begin{array}{c}0.0276 * * * \\
(0.0058)\end{array}$ & $\begin{array}{c}0.0276 * * * \\
(0.0068)\end{array}$ \\
\hline $\begin{array}{l}\text { High-Wage } \\
\text { Import Competition }\end{array}$ & $\begin{array}{c}0.0019 * * * \\
(0.0002)\end{array}$ & $\begin{array}{l}0.002 * * * \\
(0.0002)\end{array}$ & $\begin{array}{l}0.002 * * * \\
(0.0002)\end{array}$ & & \\
\hline $\begin{array}{l}\text { Computer Share } \\
\text { of Investment }\end{array}$ & $\begin{array}{l}-0.0516 * * * \\
(0.0166)\end{array}$ & $\begin{array}{l}-0.0505^{* * * *} \\
(0.0166)\end{array}$ & $\begin{array}{l}-0.0503^{* * * *} \\
(0.0166)\end{array}$ & $\begin{array}{l}-0.052 * * * \\
(0.0174)\end{array}$ & $\begin{array}{l}-0.052 * * * \\
(0.0202)\end{array}$ \\
\hline Industry Switcher & $\begin{array}{l}0.0236 * * * \\
(0.0065)\end{array}$ & $\begin{array}{l}0.0235^{* * * *} \\
(0.0064)\end{array}$ & $\begin{array}{l}0.0231 * * * \\
(0.0064)\end{array}$ & $\begin{array}{l}0.0135 \\
(0.0095)\end{array}$ & $\begin{array}{l}0.0135 \\
(0.0083)\end{array}$ \\
\hline Value of Shipments & $\begin{array}{l}-1.13 \mathrm{e}-07 * * * \\
(3.45 \mathrm{e}-08)\end{array}$ & $\begin{array}{l}-1.06 \mathrm{e}-07 * * * \\
(3.20 \mathrm{e}-08)\end{array}$ & $\begin{array}{l}-1.06 \mathrm{e}-07 * * * \\
(3.18 \mathrm{e}-08)\end{array}$ & $\begin{array}{l}-8.71 \mathrm{e}-08 * * * \\
(2.79 \mathrm{e}-08)\end{array}$ & $\begin{array}{l}-8.71 \mathrm{e}-08^{* *} \\
(3.68 \mathrm{e}-08)\end{array}$ \\
\hline Capital-Labor Ratio & $\begin{array}{l}-0.00003^{* *} \\
(0.00001)\end{array}$ & $\begin{array}{l}-0.00003^{* *} \\
(0.00001)\end{array}$ & $\begin{array}{l}-0.00003^{* *} \\
(0.00001)\end{array}$ & $\begin{array}{l}-0.00002^{*} \\
(0.00001)\end{array}$ & $\begin{array}{l}-0.00002 * \\
(0.00001)\end{array}$ \\
\hline Relative Age & $\begin{array}{l}-1,447.87 * * * \\
(365.5)\end{array}$ & $\begin{array}{l}-1,463.56^{* * * *} \\
(366.9)\end{array}$ & $\begin{array}{l}-1,461.00 * * * \\
(366.3)\end{array}$ & $\begin{array}{l}-1,335.08 * * * \\
(339.6)\end{array}$ & $\begin{array}{l}-1,335.08 * * * \\
(425.3)\end{array}$ \\
\hline Exports Dummy & $\begin{array}{l}-0.0307 * * * \\
(0.0051)\end{array}$ & $\begin{array}{l}-0.0299 * * * \\
(0.0051)\end{array}$ & $\begin{array}{l}-0.0299 * * * \\
(0.0050)\end{array}$ & $\begin{array}{l}-0.0294 * * * \\
(0.0059)\end{array}$ & $\begin{array}{l}-0.0294 * * * \\
(0.0058)\end{array}$ \\
\hline Log TFP & & $\begin{array}{l}-0.0267 * * * \\
(0.0059)\end{array}$ & $\begin{array}{l}-0.0267 * * * \\
(0.0059)\end{array}$ & $\begin{array}{l}-0.032 * * * \\
(0.0065)\end{array}$ & $\begin{array}{l}-0.032 * * * \\
(0.0069)\end{array}$ \\
\hline $\begin{array}{l}\text { Low-Wage Country } \\
\text { Related Party Trade }\end{array}$ & & & $\begin{array}{l}-0.0412 * * * \\
(0.0114)\end{array}$ & $\begin{array}{l}-0.0528 * * * \\
(0.0117)\end{array}$ & $\begin{array}{l}-0.0528 * * * \\
(0.0129)\end{array}$ \\
\hline Observations & 105000 & 105000 & 105000 & 47000 & 47000 \\
\hline R-squared & 0.26 & 0.26 & 0.26 & - & - \\
\hline K-P rk LM statistic & & & & 499.3 & 13.8 \\
\hline C-D Wald F statistic & - & - & - & 2596.5 & 2596.5 \\
\hline K-P Wald F statistic & - & - & - & 588.2 & 13.7 \\
\hline
\end{tabular}

Notes: Numbers of observations have been rounded to protect the confidentiality of respondents. All models include industry, region and year fixed effects and robust standard errors. Except where noted (Model 4) standard errors are clustered by NAICS. * indicates significance at the 0.1 level, ** at the 0.05 level and *** at the 0.01 level. K-P is Kleinbergen-Paap and C-D is Cragg-Donald. LPM stands for Linear Probability Model; IV stands for Instrumental Variables. 
Table 7: Low-Wage Import Competition and Plant Exit, Panel Estimation: Interactions with Low-Wage Import Competition

\begin{tabular}{|c|c|c|c|}
\hline & $\begin{array}{c}(1) \\
\text { LPM - Multiple } \\
\text { Interactions } \\
\end{array}$ & $\begin{array}{c}(2) \\
I V-\text { Without } \\
\text { Clustering } \\
\end{array}$ & 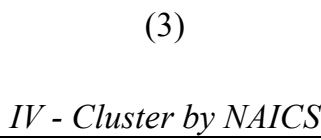 \\
\hline Low-Wage Import Competition & $\begin{array}{c}0.6969 * * * \\
(0.1587)\end{array}$ & $\begin{array}{c}8.7804 * * * \\
(0.7149)\end{array}$ & $\begin{array}{c}8.7804 * * * \\
(2.2730)\end{array}$ \\
\hline High-Wage Import Competition & $\begin{array}{c}0.0019^{* * *} \\
(0.0004)\end{array}$ & & \\
\hline Computer Share of Investment & $\begin{array}{c}-0.2132 * * * \\
(0.0162)\end{array}$ & $\begin{array}{c}-0.2023 * * * \\
(0.0112)\end{array}$ & $\begin{array}{c}-0.2023 * * * \\
(0.0153)\end{array}$ \\
\hline Industry Switcher & $\begin{array}{c}-0.0354 * * * \\
(0.0070)\end{array}$ & $\begin{array}{c}0.0058 \\
(0.0083)\end{array}$ & $\begin{array}{c}0.0058 \\
(0.0092)\end{array}$ \\
\hline Value of Shipments & $\begin{array}{c}-1.41 \mathrm{e}-07 * * * \\
(3.90 \mathrm{e}-08)\end{array}$ & $\begin{array}{c}-1.30 \mathrm{e}-07 * * * \\
(2.95 \mathrm{e}-08)\end{array}$ & $\begin{array}{c}-1.30 \mathrm{e}-07 * * * \\
(4.86 \mathrm{e}-08)\end{array}$ \\
\hline Capital-Labor Ratio & $\begin{array}{l}-0.00002^{*} \\
(0.00001)\end{array}$ & $\begin{array}{l}-0.00002 \\
(0.00002)\end{array}$ & $\begin{array}{l}-0.00002 \\
(0.00003)\end{array}$ \\
\hline Relative Age & $\begin{array}{c}-2,805.69^{* * *} \\
(254.2)\end{array}$ & $\begin{array}{c}-2,210.96 * * * \\
(220.8)\end{array}$ & $\begin{array}{c}-2,210.96^{* * *} \\
(308.4)\end{array}$ \\
\hline Exports Dummy & $\begin{array}{c}-0.0268 * * * \\
(0.0033)\end{array}$ & $\begin{array}{c}-0.0176^{* * *} \\
(0.0044)\end{array}$ & $\begin{array}{c}-0.0176^{* * *} \\
(0.0055)\end{array}$ \\
\hline Log TFP & $\begin{array}{c}-0.0188 * * * \\
(0.0042)\end{array}$ & $\begin{array}{c}0.0892 * * * \\
(0.0105)\end{array}$ & $\begin{array}{c}0.0892 * * * \\
(0.0321)\end{array}$ \\
\hline Multi-Unit Dummy & $\begin{array}{c}0.0113 \\
-0.0087\end{array}$ & $\begin{array}{c}0.0541 * * * \\
(0.0102)\end{array}$ & $\begin{array}{c}0.0541 * * * \\
(0.0133)\end{array}$ \\
\hline Low-Wage Related Party Trade & $\begin{array}{c}-0.0499 * * * \\
(0.0103)\end{array}$ & $\begin{array}{c}-0.0492 * * * \\
(0.0115)\end{array}$ & $\begin{array}{c}-0.0492 * * * \\
(0.0129)\end{array}$ \\
\hline Low-Wage Impcomp*Log TFP & $\begin{array}{c}-0.2436^{* * *} \\
(0.0701)\end{array}$ & $\begin{array}{c}-3.1975 * * * \\
(0.2761)\end{array}$ & $\begin{array}{c}-3.1975 * * * \\
(0.8406)\end{array}$ \\
\hline Low-Wage Impcomp* Ind. Switcher & $\begin{array}{c}0.0441 \\
(0.0642)\end{array}$ & $\begin{array}{c}-0.5464 * * * \\
(0.1380)\end{array}$ & $\begin{array}{c}-0.5464 * * * \\
(0.1853)\end{array}$ \\
\hline Low-Wage Impcomp* K/L & $\begin{array}{c}0.0005 \\
(0.0005)\end{array}$ & $\begin{array}{c}-0.0028^{* * * *} \\
(0.0010)\end{array}$ & $\begin{array}{l}-0.0028^{*} \\
(0.0015)\end{array}$ \\
\hline Low-Wage Impcomp*Multi-Unit & $\begin{array}{c}0.2441 * * * \\
(0.0835)\end{array}$ & $\begin{array}{c}-1.0502 * * * \\
(0.1668)\end{array}$ & $\begin{array}{c}-1.0502 * * * \\
(0.3945)\end{array}$ \\
\hline Low-Wage Impcomp*Exports Dummy & $\begin{array}{c}-0.189^{* * *} \\
(0.0456)\end{array}$ & $\begin{array}{c}-0.3003 * * * \\
(0.0826)\end{array}$ & $\begin{array}{c}-0.3003 * * * \\
(0.0917)\end{array}$ \\
\hline Observations & 330000 & 130000 & 130000 \\
\hline R-squared & 0.26 & - & - \\
\hline K-P rk LM statistic & & 389.6 & 20.0 \\
\hline C-D Wald F statistic & - & 2637.6 & 2637.6 \\
\hline K-P Wald F statistic & - & 480.9 & 20.1 \\
\hline
\end{tabular}

Notes: Numbers of observations have been rounded to protect confidentiality of respondents. All models include industry, region and year fixed effects and robust standard errors. Except where noted (Model 2) standard errors are clustered by NAICS. * indicates significance at the 0.1 level, ** at the 0.05 level and *** at the 0.01 level. K-P is Kleinbergen-Paap and C-D is Cragg-Donald. LPM stands for Linear Probability Model; IV stands for Instrumental Variables. 